\title{
Zakazane powiązania podmiotowe i bliskie powiązania pośredników ubezpieczeniowych w ustawie o dystrybucji ubezpieczeń
}

Artykuł omawia treść przepisów zakazujqcych współpracy i powiqzań pomiędzy pośrednikami ubezpieczeniowymi oraz rozpatruje znaczenie pojęcia bliskich powiqzań pomiędzy pośrednikami ubezpieczeniowymi w ustawie o dystrybucji ubezpieczeń. W tekście podjęto ponadto zagadnienia konfliktu interesów i zakazanych powiqzań podmiotowych między pośrednikami, a także pozostawania przez nich „w innych relacjach”, które mogłyby zagrażać wykonywaniu działalności w zakresie dystrybucji ubezpieczeń z zachowaniem wymogów określonych w art. 7 ust. 1 u.d.u.

Słowa kluczowe: pośrednicy ubezpieczeniowi, dystrybucja ubezpieczeń, zakazane powiązania podmiotowe, pozostawanie w innych relacjach, bliskie powiązania.

\section{Wprowadzenie}

W dniu 1 października 2018 roku weszła w życie ustawa z dnia 15 grudnia 2017 roku o dystrybucji ubezpieczeń ${ }^{1}$ (dalej: u.d.u.) implementująca do polskiego porządku prawnego Dyrektywę Parlamentu Europejskiego i Rady (UE] 2016/97 z 20 stycznia 2016 roku w sprawie dystrybucji ubezpieczeń ${ }^{2}$ (dalej: dyrektywa IDD). Dyrektywa IDD wyznacza minimalną harmonizację ${ }^{3}$, co oznacza, że państwa członkowskie mogą stworzyć przepisy idące dalej niż te wynikające z dyrektywy IDD, ale nie mogą być one sprzeczne z przepisami i celami dyrektywy. Podjęte w niniejszym artykule zagadnienie zakazanych powiązań podmiotowych między pośrednikami (art. 25 i art. 30 u.d.u.) jest właśnie przykładem skorzystania przez ustawodawcę krajowego z możliwości wprowadzenia

1. Tekst jedn. Dz. U. 2018., poz. 2210 z późn. zm.

2. Dz. Urz. UE L $26 / 19$ z 2.02.2016

3. Zobacz motyw 3 dyrektywy IDD. 
dalej idących rozwiązań zapobiegających konfliktom interesów. Przepisy zakazujące współpracy oraz powiązań kapitałowych między agentami i brokerami nie wynikaja wprost z treści przepisów dyrektywy IDD, ale treść motywu 39 dyrektywy IDD ${ }^{4}$ wskazuje na możliwość wystapienia konfliktów interesów między różnymi rodzajami działalności prowadzonej przez dystrybutorów a interesami ich klientów.

Celem artykułu jest przedstawienie treści przepisów zakazujących współpracy i powiązań między pośrednikami ubezpieczeniowymi ${ }^{5}$ oraz omówienie znaczenia ich wprowadzenia. Rozważaniom poddano także treść i cel rozumienia pojęcia bliskich powiązań między pośrednikami ubezpieczeniowymi.

\section{Pojęcie konfliktu interesów a treść zakazanych powiązań podmiotowych między pośrednikami}

Celem dyrektywy IDD było objęcie nadzorem nowych kategorii podmiotów będących dystrybutorami ubezpieczeń oraz zwiększenie bezpieczeństwa ich klientów i transparentności rynku ubezpieczeniowego. Samo pojęcie konfliktu interesów coraz częściej pojawia się w wielu aktach prawnych, jednak do tej pory nie wprowadzono do ustawodawstwa jego legalnej definicji. W literaturze przyjmuje się definicję konfliktu interesów jako sytuacji podwójnej lojalności, czyli takiej, gdy dany podmiot jest zobowiązany realizować interesy, których jednoczesne osiągnięcie nie jest możliwe. Dany podmiot znajduje się w sytuacji konfliktu interesów wtedy, gdy działając na własną korzyść (lub na korzyść pewnego podmiotu, którego interesy reprezentuje), działa jednocześnie wbrew interesowi innego podmiotu, wobec którego również powinien być lojalny (lub wbrew własnemu interesowij] ${ }^{6}$. Sytuację konfliktu interesów należy rozumieć formalnie. Naganny nie jest wiec skutek w postaci zaistniałej szkody, czy też jakiegokolwiek uszczerbku w jednym z zaangażowanych interesów, ani też jakakolwiek korzyść po stronie podmiotu, który znalazł się w sytuacji konfliktu interesów. Wystarczy sama sytuacja podwójnej lojalności, czyli konfliktu obowiązków, która rodzi określone ryzyko?. Co do zasady akcentuje się, że nakaz powstrzymania się od podejmowanych działań w sytuacji konfliktu interesów aktualizuje się już nawet przy samej tylko możliwości kolizji. Celem wprowadzenia przez ustawodawcę polskiego obecnie obowiązującego całkowitego zakazu powiązań między pośrednikami jest ochrona interesów klientów pośredników

4. „(39) Wielu pośredników ubezpieczeniowych i wiele zakładów ubezpieczeń w coraz większym stopniu prowadzi jednocześnie wiele rodzajów działalności, co zwiększa ryzyko wystapienia konfliktów interesów między tymi różnymi rodzajami prowadzonej działalności a interesami ich klientów. Dlatego też konieczne jest wprowadzenie przepisów zapewniających brak negatywnego wpływu takich konfliktów interesów na interesy klientów".

5. Przez pośrednika ubezpieczeniowego należy rozumieć agenta ubezpieczeniowego, agenta oferującego ubezpieczenia uzupełniające, brokera ubezpieczeniowego oraz brokera reasekuracyjnego, którzy wykonuja dystrybucję ubezpieczeń albo dystrybucję reasekuracji za wynagrodzeniem - art. 3 ust. 1 pkt 15 u.d.u.

6. M. Niedużak, Konflikt interesów w orzecznictwie Sqdu Najwyższego oraz sqdów apelacyjnych, „Monitor Prawniczy" 2017, nr 3, s. 123.

7. Zob. wyrok SN z 11.01.2002 r., IV CKN 1903/00. Odmiennie SN w postanowieniu z 2.04.2003 r., II K 367/02. Tak za: M. Fras, [w:] Ustawa o dystrybucji ubezpieczeń. Komentarz, [red.] M. Fras, B. Kucharski, K. Malinowska, D. Maśniak, M. Szaraniec, Wolters Kluwer, Warszawa 2019 (w druku). 
ubezpieczeniowych przed zagrożeniami wynikającymi z konfliktu interesów oraz podtrzymanie dualistycznej koncepcji pośrednictwa ubezpieczeniowego w Polsce (zachowanie odrębności obligacyjnego statusu agenta oraz brokera). Przejawem profesjonalizmu, rzetelności i uczciwości agenta ubezpieczeniowego jest lojalność wobec zakładu ubezpieczeń jako drugiej strony umowy agencyjnej, natomiast profesjonalizm, rzetelność i uczciwość brokera wyznacza jego lojalność względem klienta. Konflikt interesów w odniesieniu do pośrednika ubezpieczeniowego występuje także wtedy, gdy interesy klienta, na rzecz którego on świadczy usługi, nie są tożsame z interesami tego klienta ${ }^{8}$. Transparentność w tym zakresie przejawia się głównie: w powiązaniach i zależności od innych podmiotów mogacych mieć wpływ na świadczone przez pośrednika usługi, w systemie wynagrodzenia otrzymywanego przez pośrednika, a także w usytuowaniu prawnym pośrednika związanego, tj. określeniu podmiotów, na rzecz których agent lub broker działa ${ }^{9}$.

W uzasadnieniu do projektu u.d.u. wskazano (w znaczący sposób przyczyniły się do tego uwagi KNF, które ustawodawca ostatecznie uwzględnił), że zdefiniowanie zakazanych powiązań podmiotowych pomiędzy pośrednikami powinno być możliwie kompletne, co oznacza że powinno eliminować wszelkie możliwe stany faktyczne i prawne prowadzące do konfliktu interesów ${ }^{10}$. Takie rozwiązanie prawne z jednej strony ma zapobiec przedkładaniu własnego interesu pośrednika ubezpieczeniowego ponad interes swoich klientów, z drugiej jednak - ogranicza swobodę działalności gospodarczej pośredników ubezpieczeniowych i wymusza na nich istotne zmiany organizacyjne, jeśli by model ich działalności powodował powiązania kapitałowe przed wejściem w życie u.d.u.

\subsection{Zakazane powiązania podmiotowe między agentem a brokerem}

Zakazane powiązania podmiotowe między agentem a brokerem zostały uregulowane w art. 25 u.d.u. Przepis ten wprowadza całkowity zakaz współpracy i powiązań pomiędzy agentami a brokerami ubezpieczeniowymi. Nieobowiązująca już ustawa o pośrednictwie ubezpieczeniowym wprowadziła zakaz wykonywania przez agenta ubezpieczeniowego działalności brokerskiej oraz czynności brokerskich, nie zakazywała jednak powiązań kapitałowych pomiędzy agentem a brokerem.

Z przepisu art. 25 u.d.u. wynika, że agent ubezpieczeniowy, agent oferujący ubezpieczenia uzupełniające, osoba wykonująca czynności agencyjne, członek zarządu lub rady nadzorczej agenta ubezpieczeniowego, członek zarządu lub rady nadzorczej agenta oferującego ubezpieczenia uzupełniające, wspólnicy, o których mowa w art. 19 ust. 3 pkt 2 lit. a, członkowie zarządu, o których mowa w art. 19 ust. 3 pkt 2 lit. b, akcjonariusz lub udziałowiec agenta ubezpieczeniowego lub agenta oferującego ubezpieczenia uzupełniające oraz osoba wykonująca czynności dystrybucyjne zakładu ubezpieczeń nie mogạ wykonywać działalności brokerskiej w zakresie ubezpieczeń, posiadać akcji lub udziałów brokera ubezpieczeniowego, z wyjatkiem akcji dopuszczonych do obrotu na rynku regulowanym, ani pozostawać w innych relacjach, które mogłyby zagrażać wykonywaniu działalności w zakresie dystrybucji ubezpieczeń z zachowaniem wymogów określonych w art. 7 ust. 1.

W literaturze słusznie zauważono, że sformułowany w art. 25 u.d.u. zakaz nie obejmuje członków komisji rewizyjnej spółki, która jest agentem ubezpieczeniowym oraz spółki, która jest agentem oferującym ubezpieczenia uzupełniające. Tak samo w przypadku spółek osobowych prawa

8. $\quad$ Art. 7 ust. 1 u.d.u.

9. Zob. M. Fras, op. cit.

10. Zob. Uzasadnienia do ustawy o dystrybucji ubezpieczeń (Druk sejmowy nr 1781). 
handlowego, będących agentami ubezpieczeniowymi lub agentami oferującymi ubezpieczenia uzupełniające, zakaz ten nie dotyczy wspólników tych spółek, którzy są osobami prawnymi ${ }^{11}$. Słusznie też dostrzeżono, że z treści art. 25 u.d.u. wynika, że jedynie bezpośredni akcjonariusz lub udziałowiec agenta ubezpieczeniowego lub agenta oferującego ubezpieczenia uzupełniające nie może wykonywać działalności brokerskiej w zakresie ubezpieczeń, czynności brokerskich w zakresie ubezpieczeń, posiadać akcji lub udziałów brokera ubezpieczeniowego, co oznacza że omawianego zakazu nie należy rozciagać na dalsze struktury właścicielskie w ramach choćby grupy holdingowej ${ }^{12}$.

Przedstawiony wyżej podmiotowy i przedmiotowy zakres współpracy i powiązań wynikający $z$ art. 25 u.d.u. nie występuje, gdy powiązane podmioty:

1) nie wykonują czynności dystrybucyjnych w odniesieniu do tych samych klientów,

2) nie wykonują czynności dystrybucyjnych w odniesieniu do tych samych grup ubezpieczeń,

3) nie wykonują czynności dystrybucyjnych w odniesieniu do tych samych grup ubezpieczenia.

Ta część omówionego przepisu nie wydaje się budzić wątpliwości interpretacyjnych, a przedstawiony podmiotowy i przedmiotowy zakaz współpracy agentów z brokerami ma charakter bezwzględny. Niedopuszczalne jest także rozciaganie tego zakazu na inne sytuacje współpracy, bowiem ustawodawca w art. 25 u.d.u. szczegółowo wskazał podmioty, które nie mogạ wykonywać działalności brokerskiej w zakresie ubezpieczeń, wykonywać czynności brokerskich w zakresie ubezpieczeń oraz posiadać akcji lub udziałów brokera ubezpieczeniowego, z wyjątkiem akcji dopuszczonych do obrotu na rynku regulowanym.

Na odrębne omówienie zasługuje zakaz pozostawania przez osoby wymienione w art. 25 u.d.u. w „innych relacjach” z brokerem ubezpieczeniowym - relacjach, które mogłyby zagrażać wykonywaniu działalności w zakresie dystrybucji ubezpieczeń z zachowaniem obowiązku postępowania uczciwie, rzetelnie i profesjonalnie, zgodnie z najlepiej pojętym interesem klientów (na ten temat rozważania w pkt 1.3).

\subsection{Zakazane powiązania podmiotowe między brokerem a agentem}

Omówiony wyżej art. 25 u.d.u. jest skorelowany z art. 30 u.d.u., zgodnie z którym broker ubezpieczeniowy i broker reasekuracyjny nie moga wykonywać działalności agencyjnej ani czynności agencyjnych ${ }^{13}$.

Z przepisu art. 30 ust. 1 u.d.u. wynika, że broker ubezpieczeniowy nie może:

- wykonywać działalności agencyjnej, czynności agencyjnych, czynności dystrybucyjnych zakładu ubezpieczeń ani czynności dystrybucyjnych zakładu reasekuracji;

11. Tak M. Orlicki, Niedozwolone powiqzania między brokerami i agentami ubezpieczeniowymi, „Prawo Asekuracyjne" 2018, nr 2, s. 34-35.

12. Tak M. Ryskalczyk, [w:] Ustawa o dystrybucji ubezpieczeń. Komentarz, [red.] P. Czublun, CH Beck, Warszawa 2018, el. Legalis. Autorka wskazuje, że brak zatem przeszkód do przyjęcia takiej struktury holdingowej, w której jeden podmiot, tj. spółka holdingowa, będzie właścicielem grupy podmiotów, gdzie jednocześnie niektóre z tych podmiotów (same nie prowadząc działalności brokerskiej lub agencyjnej) będą właścicielami agenta, a inne - brokera.

13. Na podstawie art. 30 u.d.u. broker ubezpieczeniowy i broker reasekuracyjny nie moga pozostawać także w jakichkolwiek stosunkach prawnych z zakładem ubezpieczeń. Problematyka ta wykracza jednak poza temat niniejszego artykułu, który dotyczy zakazanych powiązań podmiotowych i bliskich powiązań pomiędzy pośrednikami w ustawie o dystrybucji ubezpieczeń. 
- pozostawać w stałym stosunku umownym z zakładem ubezpieczeń, zakładem reasekuracji, agentem ubezpieczeniowym lub agentem oferującym ubezpieczenia;

- być członkiem organów nadzorczych lub zarzadzających zakładu ubezpieczeń, zakładu reasekuracji, agenta ubezpieczeniowego lub agenta oferującego ubezpieczenia uzupełniające;

- posiadać akcji lub udziałów zakładu ubezpieczeń lub zakładu reasekuracji, z wyjątkiem akcji dopuszczonych do obrotu na rynku regulowanym;

- pozostawać w innych relacjach, które mogłyby zagrażać wykonywaniu działalności w zakresie dystrybucji ubezpieczeń z zachowaniem wymogów określonych w art. 7 ust. 1 u.d.u.

Z treści art. 30 ust. 6-9 u.d.u. powyższe zakazy należy odnosić również do:

1) członków organów brokera będącego osobą prawna,

2) osób, przy pomocy których broker wykonuje czynności brokerskie w zakresie ubezpieczeń lub reasekuracji, niezależnie od podstawy umownej wykonywania tych czynności,

3) osób zatrudnionych przez brokera na podstawie umowy o pracę, przy pomocy których broker nie wykonuje czynności brokerskich.

W literaturze wskazuje się, że zakazem wynikającym z art. 30 u.d.u. zostały objęte nie tylko osoby wykonujące czynności brokerskie w strukturze brokera ubezpieczeniowego, ale również pracownicy brokera, którzy nie wykonuja czynności brokerskich. Wskazano, że analogiczne rozwiązanie nie zostało natomiast przyjęte w przepisie odnoszącym się do agentów ubezpieczeniowych i agentów oferujących ubezpieczenia obowiązkowe ${ }^{14}$.

W podobnym tonie ustawodawca postanowił w sytuacji zakazu posiadania przez brokera akcji lub udziałów agenta ubezpieczeniowego lub agenta oferującego ubezpieczenia uzupełniające dopuszczonych do obrotu na rynku regulowanym. W tym przypadku broker musi jednak powiadomić o posiadanych przez siebie akcjach organ nadzoru, czego w analogicznej sytuacji nie musi czynić agent.

Watpliwości związane z omawianym zakazem wynikającym z art. 30 ust. 1 u.d.u. budzi sformułowanie „pozostawania przez brokera w stałym stosunku umownym” z agentem ubezpieczeniowym lub agentem oferującym ubezpieczenia uzupełniające. Wydaje się, że słowo stały wyłącza spod tego zakazu stosunki umowne o charakterze incydentalnym albo jednorazowym. Interpretacja taka w moim przekonaniu nie jest właściwa, choć wskazuje na to wykładnia literalna przepisu. Wydaje się, że słowo stały należałoby de lege ferenda usunąc z omawianego przepisu, bowiem niedopuszczalna wydaje się sytuacja, w której broker zawiera z agentem jednorazowy stosunek umowny lub kilka takich stosunków. W tej sytuacji ów incydentalny stosunek umowny należy analizować in casum, weryfikując, czy broker ten nie pozostaje z agentem ubezpieczeniowym w „innych relacjach”, które mogłyby zagrażać wykonywaniu działalności w zakresie dystrybucji ubezpieczeń z zachowaniem obowiązku postępowania uczciwie, rzetelnie i profesjonalnie, zgodnie z najlepiej pojętym interesem klienta. W art. 30 ust. 2 i 4 u.d.u zawarto wyjatki od zasady zakazu pozostawania brokerów w stałym stosunku umownym z agentami. Zgodnie z treścią tych przepisów zakaz pozostawania brokerów w takim stosunku umownym nie dotyczy umowy ubezpieczenia, w której broker jest ubezpieczonym lub ubezpieczającym.

Na odrębne omówienie zasługuje zakaz pozostawania przez osoby wymienione w art. 30 w „innych relacjach” z agentem ubezpieczeniowym, które to relacje mogłyby zagrażać wykonywaniu działalności w zakresie dystrybucji ubezpieczeń z zachowaniem obowiązku postępowania

14. Tak M. Orlicki, op. cit., s. 37 . 
uczciwie, rzetelnie i profesjonalnie, zgodnie z najlepiej pojętym interesem klientów (na ten temat rozważania w pkt 1.3).

\subsection{Pozostawanie przez pośredników „w innych relacjach”, które mogłyby zagrażać wykonywaniu działalności w zakresie dystrybucji ubezpieczeń z zachowaniem wymogów określonych $w$ art. 7 ust. 1 u.d.u.}

„Pozostawanie w innych relacjach” jest typowym zwrotem nieostrym. Jest to nakaz samodzielnego oceniania konkretnych stanów faktycznych skierowanych do KNF. Zwroty nieostre są konsekwencja niekompletnej wiedzy ustawodawcy i niedookreśloności jego celów. Oznacza to, że ustawodawca nie jest w stanie przewidzieć wszystkich sytuacji faktycznych i podjać decyzji o ich uregulowaniu. Niezdefiniowane zwroty nieostre upoważniają KNF do dokonywania zindywidualizowanej oceny danego stanu faktycznego, uwzględniając określone okoliczności. Są nakazami samodzielnego oceniania in concreto stanów faktycznych kierowanych do KNF. Ustalenie treści zwrotu nieostrego wymaga interpretacji tekstu oraz analizy sytuacji poszczególnego zdarzenia ad casum będącego przedmiotem nadzoru (wykładnia zwrotów nieostrych wiąże się niewątpliwie z władzą dyskrecjonalną). To pojęcie nieostre koresponduje z nadzorem sprawowanym przez KNF i może stanowić kryteria tego nadzoru ${ }^{15}$.

Należy zgodzić się z poglądem zaprezentowanym w literaturze, iż sformułowanie „zakazane jest pozostawanie przez pośredników w innych relacjach, które mogłyby zagrażać wykonywaniu działalności w zakresie dystrybucji ubezpieczeń z zachowaniem wymogów określonych w art. ? ust. 1 u.d.u." należy postrzegać jako zakaz o charakterze względnym ${ }^{16}$. Gdyż za niedozwoloną będzie uznana tylko taka relacja, w przypadku której KNF wykaże naruszenie art. $?$ ust. 1 u.d.u. ${ }^{1 ?}$

Zatem pozostawanie w „innych relacjach” będzie korespondowało z nadzorem sprawowanym przez KNF. Interpretacja tego sformułowania przez KNF nie oznacza w żadnej mierze dowolności w ocenie przez nią stanu faktycznego, gdyż im bardziej nieokreślone są przesłanki podjęcia decyzji, tym bardziej szczegółowe musi być uzasadnienie powodów jej wydania przez Komisję. To właśnie KNF jest zobowiązana do udowodnienia poprawności przyjętego przez siebie rozumienia argumentów przemawiających za przyjęciem określonego sposobu rozumowania ${ }^{18}$.

15. Więcej na ten zob. M. Szaraniec, Klauzula interesu publicznego i określenia nieostre - próba wyodrębnienia tych pojęć na gruncie ustawy o działalności ubezpieczeniowej, [w:] Ubezpieczenia gospodarcze. Zagadnienia prawne, [red.] B. Gnela, Wolters Kluwer, Warszawa 2011, s. 239-254.

16. Tak M. Orlicki, op. cit., s. 38.

17. Więcej na temat wykonywania działalności w zakresie dystrybucji ubezpieczeń z zachowaniem obowiązku postępowania uczciwie, rzetelnie i profesjonalnie, zgodnie z najlepiej pojętym interesem klientów zob. K. Malinowska, Najlepszy interes klienta - rozważania na tle regulacji o dystrybucji ubezpieczeń, [w:] Dystrybucja usług ubezpieczeniowych, [red.] B. Gnela, M. Szaraniec, Difin, Warszawa 2017, s. 108 i nast. albo M. Orlicki, Aksjologia dystrybucji ubezpieczeń - kryteria uznawania działań dystrybutora za zgodne z prawem i etyczne, [w: Dystrybucja usług ubezpieczeniowych ..., s. 19 i nast.

18. Zagrożenie takie nie występuje, gdy powiązane podmioty: 1] nie wykonują czynności dystrybucyjnych w odniesieniu do tych samych klientów, 2] nie wykonują czynności dystrybucyjnych w odniesieniu do tych samych grup ubezpieczeń, 3) nie wykonują czynności dystrybucyjnych w odniesieniu do tych samych umów ubezpieczenia. (nawet, gdy ich stronami są ci sami ubezpieczyciele i ci sami ubezpieczający). 
Konstrukcja omawianych przepisów (art. 25 i 30 u.d.u.) pozwala dostrzec nie tylko to, że ustawodawca w nich posługuje się zwrotem nieostrym, ale też że ten zwrot nieostry należy interpretować poprzez znaczenie klauzuli generalnej, jaka jest działanie w najlepiej pojętym interesie klienta ${ }^{19}$. Oznacza to, że KNF będzie w tym przypadku musiała ustalić znaczenie zwrotu nieostrego i klauzuli generalnej. Z powyższych względów należy ocenić krytycznie konstrukcję tego względnego zakazu. Ustawodawca jedynie w wyjątkowych przypadkach powinien się posługiwać zwrotami nieostrymi i klauzulami generalnymi w prawie, one bowiem zawsze powoduja niepewność w stosowaniu prawa.

Trudno w tej sytuacji będzie stworzyć KNF katalog sytuacji „pozostawania w innych relacjach”, bowiem utrudniać to może dodatkowo, każdorazowo analiza ocenianego stanu faktycznego poprzez realizację normy będącej klauzula generalną art. $?$ ust. 1 u.d.u. W związku z tym, że KNF powinna każdy zaistniały przypadek traktować indywidualnie, to zaprezentowana konstrukcja względnego zakazu będzie powodować niepewność w stosunkach prawnych.

Należy też podkreślić, że wskazana regulacja przepisów art. 25 i 30 u.d.u. ma charakter publicznoprawny, ${ }^{20}$ a naruszenie w niej zakazów skutkuje ewentualnym nałożeniem sankcji wymieniowych w art. 84 ust. 2 oraz art. 83 ust. 4 u.d.u.

Z tych względów trudno zgodzić się z poglądem, jakoby wyraźna zgoda zakładu ubezpieczeń na podjęcie przez agenta określonego rodzaju współpracy z brokerem mogła uchylać bezprawność pozostawania przez agenta ubezpieczeniowego „w innych relacjach” (chodzi o art. 25 u.d.u.) albo wyraźna zgoda klienta brokera na podjęcie przez brokera określonego rodzaju współpracy z agentem mogła uchylać bezprawność pozostawania przez brokera ubezpieczeniowego „w innych relacjach” (chodzi o art. 30 u.d.u) ${ }^{21}$. Wydaje się, że intencją ustawodawcy nie było poddawanie tego typu sytuacji ocenie klienta czy też zakładu ubezpieczeń. Tego typu wyraźne zgody w żaden sposób nie wyłączają analizy poszczególnego zdarzenia ad casum będącego przedmiotem nadzoru (kontroli) ze strony KNF (i ewentualnego nałożenia sankcji wymieniowych w art. 84 ust. 2 oraz art. 83 ust. 4 u.d.u.). Zatem przekonywujący jest pogląd, że regulacja dotycząca zakazu powiązań wydaje się mieć charakter publicznoprawny, niezależny od zapatrywania konkretnego klienta, który - nawet nie będąc konsumentem - nie zawsze zdaje sobie sprawę ze znaczenia sformułowanej zgody²2.

Przy tej okazji wyrażane są także wątpliwości, czy prezentowana regulacja ma na celu ochronę klienta pośrednika ubezpieczeniowego i osiaganie celów, jakie niesie treść dyrektywy IDD 23 . Mimo że przyjęte zakazy budzą szereg wạtpliwości, to wbrew głosom krytycznym, biorąc pod uwagę zasadniczą odrębność obligacyjnego statusu agenta oraz brokera, wydaje się jednak przynajmniej wạtpliwe, czy powiązane z sobą podmioty powinny mieć całkowitą swobodę występowania w odniesieniu do tego samego klienta w charakterze agenta albo brokera, zależnie od tego, co wydaje

19. Więcej na temat klauzul generalnych i zwrotów nieostrych w prawie ubezpieczeniowym zob. M. Szaraniec, „Klauzula interesu publicznego ...., s. 239 i cytowana tam literatura.

20. 0 tendencji publicyzacji regulacji na rynku ubezpieczeń gospodarczych zob. M. Szaraniec, Publicyzacja regulacji dystrybucji usług ubezpieczeniowych, [w:] Dystrybucja usług ubezpieczeniowych ..., s. 66-79.

21. Tak M. Orlicki, op. cit., s. 41.

22. Tak: B. Kucharski, [w:] Ustawa o dystrybucji ubezpieczeń. Komentarz...

23. Zob. M. Orlicki, op. cit., s. 41-42, w podobnym tonie M. Ryskalczyk, op. cit. 
im się w danej sytuacji wygodniejsze ${ }^{24}$. Należy mieć na względzie także wyrażony pogląd, że utrzymanie przez ustawodawcę ostrego podziału na agentów i brokerów ubezpieczeniowych zamiast proponowanego przez dyrektywę IDD podziału na agentów zależnych i niezależnych wydaje się istotną zasadą polskiego systemu prawa i stanowi dla ustawodawcy wartość samą w sobie ${ }^{25}$.

\section{Treść i znaczenie bliskich powiązań pomiędzy pośrednikami}

Z treści art. 3 ust. 1 pkt 3 u.d.u. wynika odwołanie do rozumienia „bliskich powiązań”, które zostało uregulowane w art. 3 ust. 1 pkt 2 ustawy o działalności ubezpieczeniowej i reasekuracyjnej (dalej: u.dz.u.r. $)^{26}$. Zgodnie z tą ustawą bliskie powiązania występuja w trzech przypadkach:

1) gdy dwa lub więcej podmiotów jest ze sobą powiązanych przez kontrolę, tzn. znajdują się w sytuacji, w której jeden podmiot może wywierać decydujący wpływ na działalność drugiego podmiotu (art. 3 ust. 1 pkt 2a u.dz.u.r.),

2) gdy dwa lub więcej podmiotów jest ze sobą powiązanych przez udział kapitałowy, tzn. przez posiadanie, bezpośrednio lub w wyniku powiązania przez kontrolę, co najmniej $20 \%$ praw głosu lub kapitału zakładowego innego podmiotu (art. 3 ust. 1 pkt 51 u.dz.u.r.),

3) gdy dwa lub więcej podmiotów jest trwale powiązanych przez unię personalna, tzn. kontrolę nad nimi sprawuje ta sama osoba (art. 3 ust. 1 pkt 2 b u.dz.u.r.) ${ }^{27}$.

Zgodnie z art. 170 ust. 1 pkt 11 u.dz.u.r. organ nadzoru odmawia wydania zezwolenia na wykonywanie działalności ubezpieczeniowej i reasekuracyjnej, gdy pomiędzy zakładem ubezpieczeń lub zakładem reasekuracji a inną osobą prawną lub fizyczną występują bliskie powiązania, które mogłyby stanowić dla organu nadzoru przeszkodę w sprawowaniu nadzoru.

Na gruncie ustawy o dystrybucji ubezpieczeń znaczenie pozostawania w bliskich powiązaniach pomiędzy pośrednikami należy rozpatrywać także w aspekcie uniemożliwiania sprawowania skutecznego nadzoru przez KNF. Realizacja tej tezy w u.d.u. pojawia się w sytuacji:

1) wymogów ustawowych nakładanych na agentów ubezpieczeniowych i agentów oferujących ubezpieczenia uzupełniające, którzy nie moga wykonywać działalności agencyjnej, jeżeli bliskie powiązania uniemożliwiają organowi nadzoru skuteczne sprawowanie nadzoru (art. 19 ust. 4 u.d.u.);

2) warunków umożliwiających osobie prawnej uzyskanie zezwolenia na wykonywanie działalności brokerskiej, jeżeli bliskie powiązania nie uniemożliwiają organowi nadzoru skutecznego sprawowania nadzoru (art.34 ust. 4 pkt 2 lit. c u.d.u.);

24. Tak słusznie: B. Kucharski, [w:] Ustawa o dystrybucji ubezpieczeń. Komentarz... Autor zaznacza także, że poparcie dla wyraźnie sformułowanego zakazu powiązań wyrażał wielokrotnie w swoich ustnych wypowiedziach m.in. J. Kliszcz - były Prezes Stowarzyszenia Polskich Brokerów Ubezpieczeniowych i Reasekuracyjnych.

25. Tak B. Kucharski, op. cit.

26. Szeroko na temat bliskich powiązań miedzy agentem ubezpieczeniowym a innymi podmiotami zob. M. Romanowski, P. Haiduk, W. Grabowski, Bliskie powiqzania między agentem ubezpieczeniowym a innymi podmiotami w świetle ustawy z dnia 15 grudnia 2017 roku o dystrybucji ubezpieczeń, „Wiadomości Ubezpieczeniowe” 2018, nr 4, s. 3-13.

27. P. Wajda, [w:] Ustawa o działalności ubezpieczeniowej i reasekuracyjnej. Komentarz, [red.] M. Szczepańska, P. Wajda, Wolters Kluwer, Warszawa 201 ? 
3) danych podlegających wpisowi do rejestru agentów niebędacych osobami fizycznymi (art. 55 ust. 2 pkt 9 u.d.u.) oraz rejestru brokerów będących osobami prawnymi (art. 59 ust. 2 pkt 9 u.d.u.] - chodzi o wskazanie tożsamości osób, które maja bliskie powiązanie odpowiednio $z$ agentem ubezpieczeniowym, $\mathrm{z}$ agentem oferującym ubezpieczenia uzupełniające lub z brokerem ubezpieczeniowym ${ }^{28}$.

Bliskie powiązania realizują zasadę transparentności, która przejawia się w obowiązku ujawniania pewnych informacji w rejestrze pośredników ubezpieczeniowych, przy czym informacje te będą dotyczyć wyłącznie pośredników niebędących osobami fizycznymi (bliskie powiązania ze swej istoty nie będą dotyczyć także osób wykonujących czynności agencyjne i czynności brokerskie).

Ustawodawca nie wyjaśnia jednak, na czym polega skuteczny nadzór ze strony KNF i w jakich okolicznościach jest on niemożliwy do wykonania. Słuszne wydaje się stwierdzenie, że powiązania wydają się dopuszczalne, jeżeli są na tyle przejrzyste, że organ nadzoru może bez przeszkód sprawować kontrolę i wykonywać swoje uprawnienia nadzorcze, tzn. jest w stanie ustalić, który podmiot jest odpowiedzialny za ewentualnie stwierdzone naruszenie przepisów ustawy ${ }^{29}$.

Bliskie powiązania pośredników nie są zatem zakazami i są dopuszczalne, jeśli nie stanowia dla organu nadzoru przeszkody w sprawowaniu nadzoru. KNF jest zobowiązana kontrolować bliskie powiązania, przy czym mogą one być ewentualna przeszkodą do:

- podjęcia wykonywania działalności przez pośrednika ubezpieczeniowego tj. odmowy wydania zezwolenia dla brokera albo wpisu agenta do rejestru (nadzór przy dopuszczeniu do działalności przez pośrednika ubezpieczeniowego] albo

- wykonywania działalności przez pośrednika ubezpieczeniowego, jeśli kontrola organu nadzoru takie bliskie powiązania wykaże, czego efektem może być cofnięcie zezwolenia brokerowi i wykreślenie go z rejestru oraz wykreślenie z rejestru agentów agenta ubezpieczeniowego lub agenta oferującego ubezpieczenia uzupełniające (nadzór w trakcie wykonywania działalności przez pośrednika ubezpieczeniowego].

\section{Wnioski końcowe}

Powyższe regulacje wskazuja, że ustawodawca krajowy podtrzymał wyraźny podział na agentów i brokerów w prawie polskim zamiast proponowanego przez prawodawcę unijnego w dyrektywie IDD podziału na pośredników zależnych i niezależnych. Przepisy art. 25 u.d.u. i art. 30 u.d.u. są także efektem skorzystania przez ustawodawcę krajowego z charakteru minimalnego dyrektywy IDD i zaostrzenia wymogów ustawowych względem pośredników ubezpieczeniowych o zakazane powiązania podmiotowe.

Wydaje się, że konstrukcja części przepisów art. 25 u.d.u. i art. 30 u.d.u. zawierająca sformułowanie „pozostawania w innych relacjach” jest wątpliwa i wymaga doprecyzowania przez ustawodawcę.

28. Ta ostatnia sytuacja realizuje treść art. 3 ust.? dyrektywy IDD, który stanowi, że państwa członkowskie zapewniaja, aby właściwe organy odmawiały rejestracji, jeżeli skuteczne sprawowanie ich funkcji nadzorczych uniemożliwiają przepisy ustawowe, wykonawcze lub administracyjne państwa trzeciego regulujące jedna lub większą liczbę osób fizycznych lub prawnych, z którymi pośrednik ma bliskie powiązania lub trudności związane z egzekwowaniem tych przepisów ustawowych, wykonawczych lub administracyjnych.

29. J. Nowak, [w: Ustawa o dystrybucji ubezpieczeń. Komentarz, [red.] P. Czublun, CH Beck, Warszawa 2018, el. Legalis. 
W tym kształcie wymaga ona od KNF interpretacji pojęcia nieostrego (tj. pozostawania w innych relacjach] przy uwzględnieniu potencjalnego zagrożenia, że pośrednik ubezpieczeniowy nie wykonuje czynności dystrybucyjnych, postępując uczciwie, rzetelnie i profesjonalnie, zgodnie z najlepiej pojętym interesem (klauzula generalna). Tak skonstruowane przepisy powodują niepewność w stosowaniu prawa. Trudno w tej sytuacji będzie stworzyć KNF katalog sytuacji „pozostawania w innych relacjach", bowiem utrudniać to może dodatkowo, każdorazowo analiza ocenianego stanu faktycznego poprzez realizację normy będącej klauzula generalną art. $?$ ust. 1 u.d.u.

Zakazy o charakterze względnym i bezwzględnym wynikające z art. 25 u.d.u. i art. 30 u.d.u. maja charakter publicznoprawny, a ich nieprzestrzeganie przez pośrednika ubezpieczeniowego może spowodować nałożenie sankcji przez KNF w efekcie wykonanych czynności kontrolnych. Z tego powodu nawet względne zakazy w nich zawarte nie mogą być wyłączone poprzez wyraźne oświadczenia - co do zgody na wzajemne pozostawanie pośredników ubezpieczeniowych (i innych osób wskazanych w tych przepisach) w innych relacjach, które mogłyby zagrażać wykonywaniu działalności w zakresie dystrybucji ubezpieczeń z zachowaniem wymogów określonych w art. ? ust. 1 u.d.u. - innych niż pośrednicy podmiotów prawa.

Względnego zakazu pozostawania w innych relacjach zagrażających wykonywaniu działalności w zakresie dystrybucji ubezpieczeń w sposób zgodny z art. $?$ ust. 1 u.d.u. nie można utożsamiać z występowaniem bliskich powiązań pomiędzy pośrednikami ubezpieczeniowymi, bowiem bliskie powiązania nie są zakazami i będą dopuszczalne, jeśli nie stanowią dla KNF przeszkody w sprawowaniu nadzoru.

\section{Wykaz źródeł}

Fras M., [w:] Ustawa o dystrybucji ubezpieczeń. Komentarz, Fras M., Kucharski B., Malinowska K., Maśniak D., Szaraniec M., Wolters Kluwer, Warszawa 2019 (w druku).

Kucharski B., [w:] Ustawa o dystrybucji ubezpieczeń. Komentarz, Fras M., Kucharski B., Malinowska K., Maśniak D., Szaraniec M., Wolters Kluwer, Warszawa 2019 (w druku).

Malinowska K., Najlepszy interes klienta - rozważania na tle regulacji o dystrybucji ubezpieczeń, [w:] Dystrybucja usług ubezpieczeniowych, Gnela B., Szaraniec M. [red.], Difin, Warszawa 2017. Niedużak M., Konflikt interesów w orzecznictwie Sqdu Najwyższego oraz sqdów apelacyjnych, „Monitor Prawniczy” 2017, nr 3.

Orlicki M., Niedozwolone powiqzania między brokerami i agentami ubezpieczeniowymi, „Prawo Asekuracyjne" 2018, nr 2.

Orlicki M., Aksjologia dystrybucji ubezpieczeń - kryteria uznawania działań dystrybutora za zgodne z prawem i etyczne, [w:] Dystrybucja usług ubezpieczeniowych, Gnela B., Szaraniec M., Difin, Warszawa 2017.

Nowak J., [w:] Ustawa o dystrybucji ubezpieczeń. Komentarz, Czublun P. [red.], CH Beck, Warszawa 2018.

Romanowski M., Haiduk P., Grabowski W., Bliskie powiqzania między agentem ubezpieczeniowym a innymi podmiotami w świetle ustawy z dnia 15 grudnia 2017 roku o dystrybucji ubezpieczeń, „Wiadomości Ubezpieczeniowe” 2018, nr 4.

M. Ryskalczyk, [w:] Ustawa o dystrybucji ubezpieczeń. Komentarz, Czublun P. [red.], CH Beck, Warszawa 2018. 
Szaraniec M., Publicyzacja regulacji dystrybucji usług ubezpieczeniowych, [w:] Dystrybucja usług ubezpieczeniowych, Gnela B., Szaraniec M. [red.], Difin, Warszawa 2017.

Szaraniec M., Klauzula interesu publicznego i określenia nieostre - próba wyodrębnienia tych pojęć na gruncie ustawy o działalności ubezpieczeniowej, [w:] Ubezpieczenia gospodarcze. Zagadnienia prawne, Gnela B. [red.], Wolters Kluwer, Warszawa 2011.

Wajda P., [w: ] Ustawa o działalności ubezpieczeniowej i reasekuracyjnej. Komentarz, Szczepańska M., Wajda P. [red.], Wolters Kluwer, Warszawa 201 ?

\section{Prohibited personal connections and close links of insurance intermediaries in the Act on insurance distribution}

The article discusses the content of regulations prohibiting cooperation and connections and the meaning of the concept of close links between insurance intermediaries in the Act on insurance distribution. The article deals with the problem of the concept of conflict of interest and the content of prohibited subjective connections between intermediaries, as well as their remaining in "other relationships" that could threaten the activities in the field of insurance distribution in compliance with the requirements set out in Article 7 item 1 reg.

Keywords: intermediaries, insurance distribution, prohibited personal connections, remaining in other relationships, close connections.

DR HAB. PROF. UEK MONIKA SZARANIEC - specjalistka w zakresie prawa gospodarczego publicznego, w szczególności prawa ubezpieczeń gospodarczych; Uniwersytet Ekonomiczny w Krakowie, Kolegium Ekonomii, Finansów i Prawa, Instytut Prawa, Katedra Prawa Gospodarczego Publicznego i Prawa Pracy.

e-mail: monika.szaraniec@uek.krakow.pl

nr orcid: 0000-0002-3721-3179 
